\title{
Complications of Typhoid fever and its antibiotic regimen in a university hospital
}

Remedios Fabra-Coronel

\begin{abstract}
Abstrak
Demam tifoid masih merupakan masalah di Filipina karena insidennya yang meningkat, terlihat dari kasus-kasus yang ada sepanjang tahun. Karena itu, selama tiga tahun terakhir, Juni 1994 - Mei 1997, kami telah mencatat kasus-kasus demam tifoid yang terbukti dengan biakan, serta komplikasinya. Tercatat 261 pasien, 99 di antaranya pasien pediatri dan 162 pasien dewasa. Tidak ada pasien dari kelompok pediatri yang mengalami komplikasi. Pada 162 pasien dewasa, 42 mengalami komplikasi, yaitu : perdarahan (14), psikosis (13), hepatitis (7), pneumonia (2), glomerulonefritis (2), sistitis hemoragika (2), artritis septik (I), dan relaps (1). Terlihat bahwa masa sakit sebelum ke-42 pasien ini masuk rumah sakit berkisar antara 14 - 25 hari. Isolat Salmonella typhi merupakan galur yang sensitif. Walaupun galur tersebut sensitif, antimikroba yang diberikan secara empiris adalah obat lini kedua atau obat alternatif, yaitu siprofloksasin, pelloxacin, ofloksasin, seftriakson, kecuali untuk glomerulonefritis dan sistitis hemoragika diberikan kotrimoksasol. Tidak ada kematian tercatat pada seluruh penderita. Pemberian antibiotika yang tepat dengan cara yang tepat pada penderita dengan dan tanpa komplikasi berperan penting pada kesembuhan mereka.
\end{abstract}

\begin{abstract}
Typhoid fever is still a problem in the Philippines because of its increasing incidence as shown by cases seen all year round. Because of this, during the past three years June 1994 - May 1997, we have recorded our culture proven typhoid fever cases and their complications. There were 261 patients, 99 of whom are pediatrics and 162 adults patients. None of the pediatric group developed complication. In the 162 adults patients, 12 developed complications, namely hemorrhage (14), psychosis (13), hepatitis (7), pneumonia (2), glomerulonephritis (2), hemorrhagic cystitis (2), septic arthritis (1), and relapse (1). It was observed that the duration of illness prior to admission in these 42 patients with complications ranged from $14-25$ days. The Salmonella typhi isolates were sensitive strains. Despite the sensitive strains, the empiric antimicrobials administered were the $2^{\text {nd }}$ line drugs or the alternative drugs, namely, Ciprofloxacin, Pefloxacine, Ofloxacin, Ceftriaxone except for the glomerulonephritis and hemorrhagic cystitis of which Co-trimoxazole was given. No mortality was noted in all the patients. The prompt administration of the appropriate antimricrobials in those patients with complications as well as these patients without complications played a very important role in their survival.
\end{abstract}

